\title{
ЗБЕРЕЖЕННЯ РОДЮЧОСТІ ЧОРНОЗЕМІВ ЗВИЧАЙНИХ В УМОВАХ АРИДИЗАЦІЇ КЛІМАТУ
}

\author{
О. В. ПІКОВСЬКА, кандидат с.-г. наук, доцент кафедри ґрунтознавства \\ та охорони грунтів ім. проф. М. К. Шикули \\ E-mail: pikovska_olena@ukr.net \\ ORCID iD https://orcid.org/0000-0002-5052-9223 \\ Національний університет біоресурсів і природокористування України
}

\begin{abstract}
Анотація. В сучасних умовах змін клімату, що впливають на ріст та розвиток сільськогосподарських культур, актуальною є оцінка різних агротехнічних заходів за їх впливом на показники родючості грунтів. Важливу роль у технологіях вирощування відіграють системи обробітку грунту. Метою наших досліджень було встановлення впливу систем обробітку грунту в Північному Степу України на окремі показники родючості чорнозему звичайного. У досліді вивчали три системи обробітку: полицеву оранку на 23-25 см, мінімальний обробіток на 4-5 см і нульовий обробіток (прямий висів). У зразках грунту визначали вміст загального гумусу за методом Тюріна в модифікації Сімакова, структурно-агрегатний склад методом просіювання за Саввіновим, вологість грунту ваговим методом із розрахунком продуктивної вологи за різницею між фактичною вологістю та вологістю в'янення. Застосування прямого висіву та мінімального обробітку грунту забезпечували формування дефлячійно стійкої поверхні 0-10 см шару грунту: вміст агрегатів розміром понад 1 мм складав відповідно 62 і $60 \%$, тоді як на варіанті з оранкою - 49\%. Вміст гумусу у шарі 0-30 см складав відповідно 4,58 \% за нульового обробітку; 4,57 - за мінімального і 4,52 \% за оранки. Мінімізація обробітку грунту також вищі запаси продуктивної вологи в метровій товщі грунту порівняно з традиційною оранкою.
\end{abstract}

Ключові слова: родючість грунту, аридизація клімату, чорнозем звичайний, продуктивна волога, нульовий обробіток, гумус, дефляційна стійкість грунту

\section{Актуальність.}

В Україні протягом останніх років відмічають зростання впливу глобального потепління на кліматичні умови. Аграрний сектор є головним в економіці країни, тому важливо адаптувати технології вирощування культур до нинішніх кліматичних умов. Провід- ні метеорологи України зазначають, що сільське господарство $є$ найбільш вразливою галуззю економіки України до коливань і змін клімату. Враховуючи інерційний характер сільського господарства та залежність його ефективності від погодних умов, уже зараз необхідне прийняття своєчасних та адекватних рішень щодо складних 
проблем, обумовлених змінами клімату (Польовий А. М., Кульбіда М. І., Адаменко T. I., Трофімова I. В., 2007). На викиди парникових газів впливають багато факторів, зокрема вміст в грунті карбону та елементів живлення (Sun, X., Tang, Z., Ryan, M. G., You, Y., \& Sun, O. J., 2019).

\section{Аналіз останніх досліджень та публікацій.}

Питанням пошуку оптимальних систем обробітку грунту за впливом на урожайність культур присвячена значна увага вчених. Водночас важливим $є$ вплив різних систем обробітку грунту на показники родючості, особливо в умовах сучасних глобальних змін клімату.

Dekemati, I., Simon, B., Vinogradov, S., \& Birkás, M. (2019) зазначають, що історично обробіток грунту виконував завдання підготовки до висіву насіння та боротьби з бур'янами, проте він прискорив деградацію грунту через ерозію і втрату органічної речовини грунту. На основі дослідження різних систем обробітку грунту за впливом на структурно-агрегатний склад, кількість дощових черв'яків, реакцію грунтового середовища і вміст органічної речовини, встановлено, що для поліпшення як фізичних, так і біологічних властивостей грунтів слід зменшувати інтенсивність обробітку грунту.

Нульовий обробіток у світі застосовується як альтернатива традиційним технологіям вирощування культур. Li, Y., Li, Z., Cui, S., \& Zhang, Q. (2020) проаналізувавши 264 публікації $з$ питань нульового обробітку, кількісно визначили за допомогою інтенсивного мета-аналізу, що вплив No-till на фізичні властивості грунту досить складний і значною мірою залежить від кліматичних умов, тривалості експерименту та текстури грунту. Вони вказують, що саме кліматичні умови $\epsilon$ визначальними за впливом на ефективність нульового обробітку (Li, Y., Li, Z., Cui, S., \& Zhang, Q., 2020). Саме тому важливим $є$ дослідження впливу таких систем обробітку в конкретних грунтово-кліматичних умовах у тривалих дослідах.

Важливу роль у збереженні грунтів сільськогосподарських угідь, зменшенні впливу кліматичних змін має стійкість структурних агрегатів грунту та органічна речовина грунту. Різні системи обробітку грунту можуть впливати на структуру грунту та вміст карбону, а отже, і на екологічну безпеку сільськогосподарських угідь (Wang, X. at al., 2019). Про тісний взаємозв'язок структури грунту та вмісту гумусу вказано в роботах ряду вчених (Guo, Y. at al., 2020; Бережняк М.Ф., Бережняк Є.M., 2010; Піковська О.В., Вітвіцька О.I., 2016; Булигін С.Ю., Величко В.А., Демиденко О.В., 2016).

Метою досліджень була оцінка змін показників родючості чорноземів звичайних за різних систем обробітку грунту в умовах аридизації клімату.

\section{Методи дослідження.}

Дослідження проводили у тривалому досліді в Дніпропетровської області у полі кукурудзи на силос. Грунт дослідної ділянки - чорнозем звичайний середньогумусний важкосуглинковий на лесі з вмістом гумусу 4,60\%, нейтральною реакцією грунтового середовища. Дослід включав три варіанти систем обробітку грунту: оранку на 23-25 см; мінімальний обробіток на 4-5 см і прямий висів (нульовий обробіток, No-till). Систе- 
ми удобрення та захисту рослин були однакові на всіх варіантах досліду.

У зразках грунту визначали вміст загального гумусу за методом Тюріна в модифікації Сімакова, структурно-агрегатний склад методом просіювання за Саввіновим, вологість грунту ваговим методом із розрахунком продуктивної вологи за різницею між фактичною вологістю та вологістю в'янення.

Результати та їх обговорення.

Дефляційно стійкими вважаються агрегати розміром понад 1 мм. За їх вмісту понад $60 \%$ дефляція не виникає. Системи обробітку грунту безпосередньо впливали на вміст таких часток за вирощування кукурудзи на силос (рис. 1).

Вітрова ерозія $є$ однією 3 найбільших загроз грунтовому вкриттю степової зони, із зростанням посушливості клімату, іiі руйнівний вплив лише збільшується. Аналізуючи результати досліджень, слід відзначити грунтозахисну роль мінімізації обробітку грунту. В зоні Степу значної шкоди посівам культур завдають весняні пилові бурі, які видувають верхній шар грунту. Саме тому важливо забезпечити оптимальний структурний стан поверхні грунту у верхньому 0-10 см шарі грунту. Найвищий вміст агрегатів розміром понад 1 мм у цьому шарі відмічено за нульового обробітку і він складав $62 \%$, за мінімального поверхня також була дефляційно стійкою, тоді як на варіанті з оранкою вміст часток понад 1 мм складав лише 49 \%. Аналогічна тенденція спостерігалась і в нижніх шарах грунту. Загалом протягом весняно-літнього періоду за вирощування кукурудзи на силос найкращу дефляційну стійкість поверхні за вмістом агрегатів понад 1 мм було відмічено за прямого висіву.

Інтегральним показником родючості грунту є вміст гумусу. На рис. 2 представлено вміст гумусу у чорноземі звичайному.

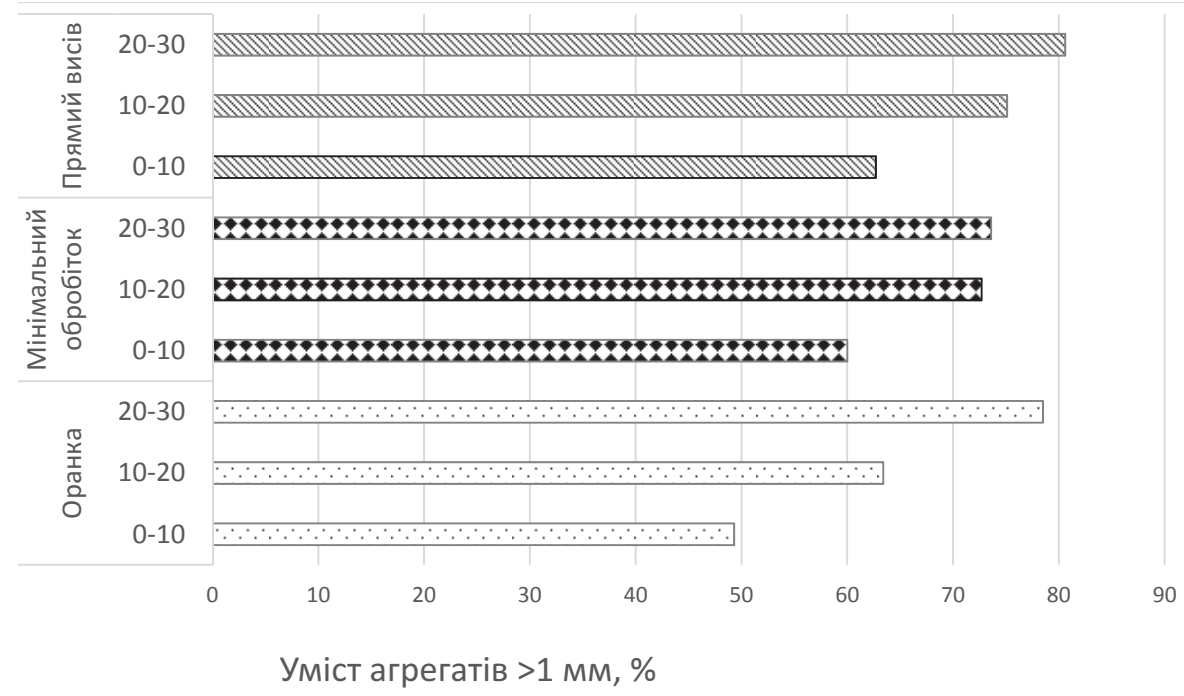

Рисунок 1. Вплив систем обробітку грунту на вміст дефляційно стійких агрегатів у чорноземі звичайному 


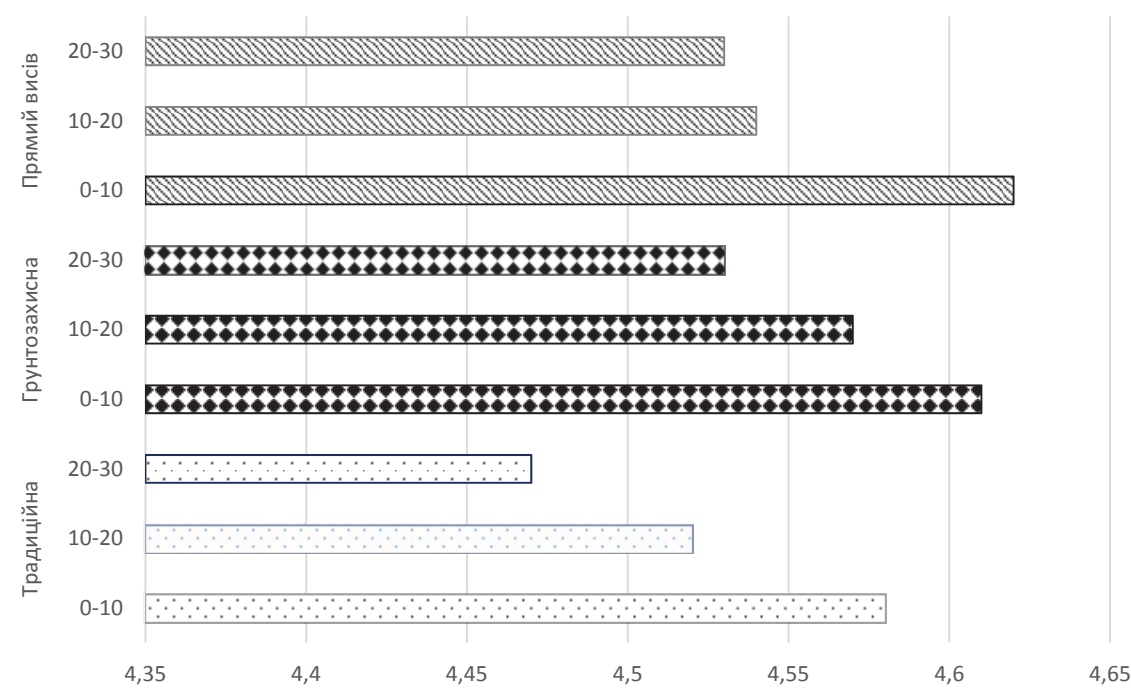

Рисунок 2. Вміст гумусу чорнозему звичайного за різних систем обробітку грунту, \%

Дослідженнями вчених кафедри грунтознавства та охорони грунтів ім. проф. М.К.Шикули НУБіП України встановлено позитивний вплив мінімізації обробітку грунту на показники гумусового стану (Бережняк М.Ф., Бережняк С. М., 2010; Піковська О.В., 2012; Тихенко О.В., 2006; Тонха О.Л., Піковська О.В., 2015; Тонха О.Л., Балаєв А.Д, Вітвіцький С.В., 2017).

Зниження інтенсивності обробітку чорнозему звичайного забезпечило збереження органічної речовини. У 0-10 см вміст гумусу за прямого висіву складав 4,62; за мінімального $4,61 \%$, тоді як за оранки $-4,58 \%$. У середньому в шарі 0-30 см вміст гумусу складав відповідно 4,58 \% за нульового обробітку; 4,57 - за мінімального i 4,52\% за оранки. Слід відзначити позитивний вплив як мінімального, так і нульового обробітків у запобіганні дегуміфікації грунтів. Враховуючи закріплення карбону у гумусі, варто відзначити також зниження його втрат у вигляді вуглекислого газу. У дослідженнях О.В.Демиденка встановлено вплив різних систем удобрення у короткоротаційних сівозмінах на секвестрацію карбону, що дуже важливо в умовах змін клімату (Demydenko O., Zapasna Y., Velychko V., 2018).

В умовах аридизації клімату важливою $\epsilon$ оцінка вологозберігаючого ефекту різних агротехнічних заходів. На рис. 3 представлені результати визначення запасів продуктивної вологи чорнозему звичайного.

Протягом вегетаційного періоду запаси вологи в грунті закономірно зменшувались. Як свідчать результати визначення, застосування прямого висіву забезпечило найвищі запаси продуктивної вологи протягом весняно-літнього періоду - 44-112 мм у метровій товщі грунту. Дещо нижчі запаси відмічені за мінімального обробітку - 40-105 мм. Застосування оранки зумовило найгірше збереження вологи у 0-100 см шарі на рівні 35-98 мм. 


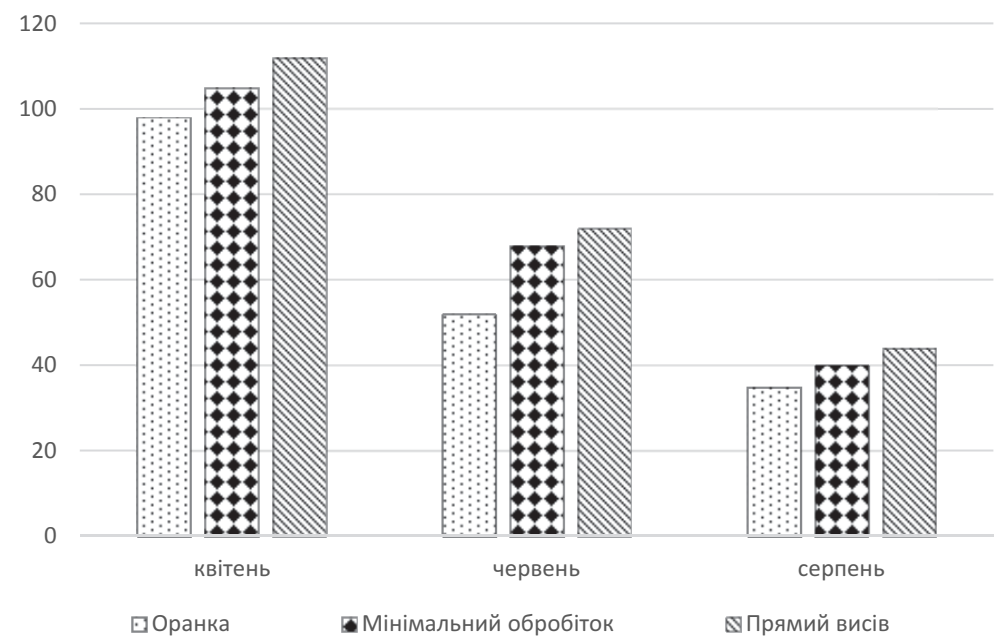

\section{Рисунок 3. Запаси продуктивної вологи 0-100 см шару чорнозему звичайного за вирощування кукурудзи на силос, мм}

\section{Висновки.}

У результаті проведених досліджень встановлено, що застосування мінімального та нульового обробітку грунту забезпечує збереження родючості чорнозему звичайного в умовах Північного Степу України.

Вміст агрегатів розміром понад 1 мм у 0-10 см шарі чорнозему звичайного за мінімального обробітку складав $60 \%$, за нульового - $62 \%$, тобто поверхню грунту можна вважати дефляційно стійкою, тоді як за оранки вміст часток був лише $49 \%$.

Зниження інтенсивності обробітку чорнозему звичайного забезпечило збереження органічної речовини: у шарі 0-30 см вміст гумусу складав відповідно 4,58 \% за нульового обробітку; 4,57 - за мінімального і 4,52 \% за оранки. Застосування прямого висіву забезпечило найвищі запаси продуктивної вологи у метровій товщі грунту протягом весняно-літнього періоду, за оранки - найменші.

\section{References}

1. Pol'ovyy A. M., Kul'bida M. I., Adamenko T. I., Trofimova I. V. (2007). Modelyuvannya vplyvu zminy klimatu na ahroklimatychni umovy vyroshchuvannya ta fotosyntetychnu produktyvnist' ozymoyi pshenytsi v Ukrayini [Modeling the impact of climate change on agricultural growing conditions and photosynthetic productivity of winter wheat in Ukraine]. Ukr. hydrometeorol. journal. No. 2. P. 76-91.

2. Sun, X., Tang, Z., Ryan, M. G., You, Y., \& Sun, O. J. (2019). Changes in soil organic carbon contents and fractionations of forests along a climatic gradient in china. Forest Ecosystems, 6(1) doi:10.1186/s40663-019-0161-7

3. Dekemati, I., Simon, B., Vinogradov, S., \& Birkás, M. (2019). The effects of various tillage treatments on soil physical properties, earthworm abundance and crop yield in hungary. Soil and Tillage Research, 194 doi:10.1016/j.still.2019.104334.

4. Li, Y., Li, Z., Cui, S., \& Zhang, Q. (2020). Trade-off between soil pH, bulk density and other soil physical properties under global no-tillage agriculture. Geoderma, 361 doi:10.1016/j.geoderma.2019.114099 
5. Wang, X., Qi, J. -., Zhang, X. -., Li, S. -., Latif Virk, A., Zhao, X., . . . Zhang, H. -. (2019). Effects of tillage and residue management on soil aggregates and associated carbon storage in a double paddy cropping system. Soil and Tillage Research, 194 doi:10.1016/j.still.2019.104339

6. Guo, Y., Fan, R., Zhang, X., Zhang, Y., Wu, D., McLaughlin, N., . . . Liang, A. (2020). Tillage-induced effects on SOC through changes in aggregate stability and soil pore structure. Science of the Total Environment, 703 doi:10.1016/j.scitotenv.2019.1346174

7. Berezhnyak M.F., Berezhnyak YE.M. (2010) Optymizatsiya ahrofizychnykh parametriv chornozemnykh gruntiv za riznykh system obrobitku. [Optimization of Agrophysical Parameters of Black Earth Soils under Different Processing Systems.] Visnyk ahrarnoyi nauky. №12. P. 16-19. file:///C:/Users/user/ AppData/Local/Packages/Microsoft.MicrosoftEdge_8wekyb3d8bbwe/TempState/ Downloads/vaan_2010_12_4\%20(1).pdf

8. Pikovska O. V, Vitvitska O. I. (2016) Vplyv zastosuvannya solomy na pokaznyky rodyuchosti chornozemu typovoho. [Influence of straw application on fertility indexes of typical chernozem]. Naukovyy visnyk Natsional'noho universytetu bioresursiv i pryrodokorystuvannya Ukrayiny. Seriya : Ahronomiya. Vyp. 235. P. 160-166. URL: http://nbuv.gov. ua/UJRN/nvnau_agr_2016_235_21

9. Bulyhin S.YU., Velychko V.A., Demydenko O.V. (2016) Ahrohenez chornozemu. [Agrogenesis of chernozem]. K.: Ahrarna nauka, 356 p.

10. Pikovska O. V. (2012) Vplyv riznykh system obrobitku gruntu na vmist i dynamiku humusu chornozemu zvychaynoho. [Influence of different soil tillage systems on the content and dynamics of humus of chernozem ordinary]. Naukovyy visnyk Natsional'noho universytetu bioresursiv i pryrodokorystuvannya Ukrayiny. Ser.: Ahronomiya. Vypusk 176. P.170-173

11. Tykhenko O. V. (2006). Obhruntuvannya ta efektyvnist' gruntozakhysnoho zemlerobstva pry vyroshchuvanni ozymoyi pshenytsi. [Rationale and effectiveness of soil protection technologies of growing winter wheat]. Visnyk ahrarnoyi nauky Prychornomor"ya. 4. 2006. (37) tom 1.

12. Tonkha O.L., Pikovs'ka O. V. (2015). Gruntozakhysni tekhnolohiyi vyroshchuvannya sil's'kohospodars'kykh kul'tur i yakisnyy sklad orhanichnoyi rechovyny chornozemiv. [SOIL CONSERVATION TECHNOLOGY OF CROP GROWING AND QUALITATIVE COMPOSITION OF SOIL ORGANIC MATTER OF CHERNOZEMS]. Naukovi dopovidi NUBiP Ukrayiny. Vypusk 2 (51). http://journals.uran.ua/index.php/22231609/article/viewFile/116910/110940

13. Demydenko O., Zapasna Y., \& Velychko V. (2018). Sequestration of carbon oxide in different fertilization systems in agrocenoses. Agricultural Science and Practice, 5(2), 37-51. https://doi.org/10.15407/agrisp5.02.037

14. Tonkha O.L., Balayev A.D., Vitvits'kyy S.V. (2017) Biolohichna aktyvnist' i humusnyy stan chornozemiv Lisostepu i Stepu Ukrayiny. Monohrafiya. [Biological activity and humus status of the Black Forests of the Steppe and Steppe of Ukraine. Monograph.]. K.: Vydavnytstvo, 355 p. http://dglib.nubip.edu.ua:8080/jspui/handle/123456789/5117

\section{Pikovska O. (2020). CONSERVATION OF FERTILITY OF CHERNOZEM ORDINARY IN THE CONDITION OF CLIMATE ARIDIZATION. PLANT AND SOIL SCIENCE, 11(1): 62-68. https://doi.org/10.31548/agr2020.01.062}

Abstract. In the current climate change, affecting the growth of crops, it is relevant to evaluate various agrotechnical measures for their impact on soil fertility. Soil tillage systems play an important role in technologies of growing crops. The purpose of our research was to determine 
the impact of tillage systems in the Northern Steppe of Ukraine on fertility parameters of chernozem ordinary. In the experiment, three tillage systems were studied: plowing by 23-25 sm, minimum tillage by 4-5 sm and no-tillage (direct seeding).

In soil samples we determined the total humus content by the Tyurin method in the Simakov modification, the structural aggregate composition by the method of Savinov, the moisture content of the soil by the weight method. The use of no-tillage and reduced tillage provided the formation of a deflation-resistant surface of 0-10 cm soil layer: the content of aggregates larger than $1 \mathrm{~mm}$ was 62 and $60 \%$, in the plowing variant - $49 \%$. The humus content in the $0-30 \mathrm{~cm}$ layer was $4.58 \%$ in No-tillage variant, 4.57 - in reduced tillage and $4.52 \%$ for the plowing. Reducing tillage is also higher reserves of productive moisture in a meter layer of comparative with traditional plowing.

Keywords: soil fertility, climate aridization, chernozem ordinary, productive moisture, no tillage, humus, soil deflation 